\title{
Eugène Emmanuel Viollet-le-Duc and monument protection: A case study
}

This article analyses the importance and influence of Eugène Emmanuel Viollet-le-Duc's mid-nineteenth-century monument-protection approaches to saving architectural monuments that were received critically by both his contemporaries and later developers of monument-protection principles. A case study is used to demonstrate deviations in Slovenian monument protection, which has been historically and professionally committed to the conservation principles of the Vienna school. A number of procedures for restoring architectural structures in the sense of Viollet-le-Duc's approaches were carried out in practice, not only after the Second World War, when such interventions became more common due to extensive damage during the war, but also several decades after that. The study shows that reconstruction measures are carried out for various reasons, but that they always reflect the historical context in which they are created.

Key words: Eugène Emmanuel Viollet-le-Duc, conservation, reconstruction, authenticity 


\section{Introduction}

Many premises and principles connected with the manner of protecting heritage have been developed throughout history that consequently influenced the development of modern protection methodologies. Every period evaluated heritage in a specific way, had a specific attitude towards it and used specific guidelines on safeguarding and protecting monument heritage. Theories and authors' reflections have complemented and contradicted one another, creating new approaches and perspectives (Jokilehto, 1999). The traditional conservation of historical monuments, Romantic restoration and the concept of minimal interventions created in that same period roughly represent the three different historical approaches to saving monuments; they are now increasingly included in international documents and recommendations that direct the management of world heritage during globalisation (Lah, 2001). In the nineteenth century, the Frenchman Eugène Emmanuel Viollet-le-Duc (1814-1879) and the Englishman John Ruskin (1819-1900) were the leading figures of architectural monument-protection theory. However, they approached monuments with completely opposing concepts, methods and goals. These two different protection and conservation directions were key to later generations, both in terms of shaping new interpretations and concepts, and in the development of modern monument protection (Frampton, 1992).

Viollet-le-Duc's principles of addressing monuments predominated across most of Europe, whereas Ruskin's approaches, which were aimed at preserving the uniqueness, originality and truth, were mainly used in his native England. However, in the last quarter of the nineteenth century, Viollet-le-Duc's principles slowly began to give way to new methodological heritage-preservation approaches (Choay, 2001). Representatives of the other conservation direction, the so-called "fathers" of monument protection - John Ruskin, William Morris (1834-1896), Camillo Boito (1836-1914), Georg Dehio (1850-1932), Alois Riegl (1858-1905) and Max Dvořák (1874-1921) - strongly opposed the architectural renovation and monument interventions following Violletle-Duc's principles of "truth". Hence even many years after Viollet-le-Duc's death anything following his principles was considered bad.

The criticism directed at Viollet-le-Duc's interventions referred to the issue of authenticity. In contrast to Ruskin's goal of preserving uniqueness, originality and truth, Viollet-le-Duc made up the truth by updating architecture and adding architectural elements that had never existed. Through his "stylistic cleaning", he removed younger parts of monuments that did not date back to the Middle Ages and replaced them with


Figure 1: a) Plan for a vaulted hall, sketch by Viollet-le-Duc; b) concert hall plan, sketch by Viollet-le-Duc (sources: a) Internet 1; b) Internet 2). 
new ones (Pirkovič, 2003). The philosophical approach that he applied in his radical creative work was unacceptable to many. His visions referred to the future and "the search for a hypothetical modern architecture" (Choay, 2001: 105), and especially an ideal, aesthetically perfected form. He introduced many architectural innovations using modern materials, including wrought iron and cast iron in historical buildings (Campa, 2009) to achieve both construction stability and the appearance of newness, while to some extent denying the status of a historical building (Murphy, 2000). Such daring and aggressive interventions raised doubt and disapproval among those that did not share his views.

Slovenian monument-protection theory is based on the Austrian heritage-protection doctrine, whose main proponent during the interwar period was France Stele. Later art historians had a broader scope of thought on protection, which led to different methods. This article examines where the adopted principles deviated from the Vienna school, and whether a parallel with Viollet-le-Duc's theory and potential influence on Slovenian monument protection can be drawn at all.

\section{Eugène Emmanuel Viollet-le-Duc}

The French Revolution was an important breaking point in history. This was a period of vandalism, which left behind a devastated landscape and ruined monuments. In these circumstances, specific interventions on monuments were urgent and the reminders of the past could only be saved through extensive restoration and reconstruction (Mušič, 1963). Based on detailed studies, analyses and aesthetic endeavours, Viollet-leDuc provided a new insight into preserving inherited buildings during this turbulent period. His career advanced significantly after the approval and implementation of his restoration project in Vézelay, which represents one of his most characteristic works. In addition to architecture and history, Viollet-le-Duc was also interested in statics, medicine and anatomy; his interest in the last two was of course only limited to theoretical findings.

\subsection{Viollet-le-Duc's quest for the truth}

In his two-volume book Entretiens sur l'architecture (Lectures on Architecture), in which he systematised his approach to architecture and architectural education, Viollet-le-Duc wonders whether the nineteenth century is destined to end without its own architecture that will only bring "imitations without character" to future generations, and what the benefit is of constantly copying forms already proven (1987: 446). However, due to negative evaluation of architecture, nineteenth-century architecture is in fact labelled as one without any "artistic value" and even researchers dedicated very little attention to it until the 1960s (Lazarini, 2012: 19). Interventions carried out during this period left a significant mark on European monuments and caused a split between their supporters and opponents. "Removing and adding by being convinced that architecture is not prestigious enough can be interpreted as a symptom of Europeans' lack of criticism towards their own past" (Špikić, 2006: 91-92).

In order to avoid the monotony of copying and losing the "truth" or originality, to be "true in respect of the programme, and true in respect of the constructive process" was of primary importance to Viollet-le-Duc, and "what are regarded as questions purely belonging to art, symmetry and external form are only secondary conditions" (1987: 448). With this mindset he opened the door to his grand modifications and took the right to make changes and additions at his own discretion. His writings reveal a burning desire to create new architecture, but also awareness that his desires cannot be fulfilled. He wrote about his own efforts and called out to other architects to "prepare the ground" for future generations by seeking "new adaptations in harmony ... and so far from losing sight of the past let us rise above it by building upon it" (1987: 88). According to Francoise Choay (2001: 105), he "returned to the restored object a historical value, but not its historicity". He tried to restore value to what was created in the past, but the question is what the difference is between, as he wrote, "imitations without character" and fictitious forgeries with character. Both cases result in unoriginal architecture, which may gradually become an authentic monument of its time (Gams, 2010) and influence collective memory and national identity (Giliberti, 2013).

The interpretation of the concept of authenticity has varied throughout history; according to Čepaityte Gams (2010), this term was largely defined by the Romanticists and their contemporaries around 1800. Viollet-le-Duc's concern for seeking the "truth" contains traces or at least awareness of seeking the original. With a rationalist logic, his work followed a specific order of Descartes' four principles: research divided into smaller manageable units, starting with simpler and more comprehensible ones that gradually lead to broader and more complex ones, or to discovering the truth. He paid special attention to what was undiscovered and processed even the smallest details with great precision (Viollet-le-Duc, 1987). In searching for the "truth" and fulfilling the demand for perfection and appearance of value, he prioritised the last two, whereas the truth got lost on the way.

Viollet-le-Duc summarised his work spanning several decades in the book Dictionnaire raisonné de l'architecture française $d u$ $X I^{e}$ au XVI siecle (Dictionary of French Architecture from the 

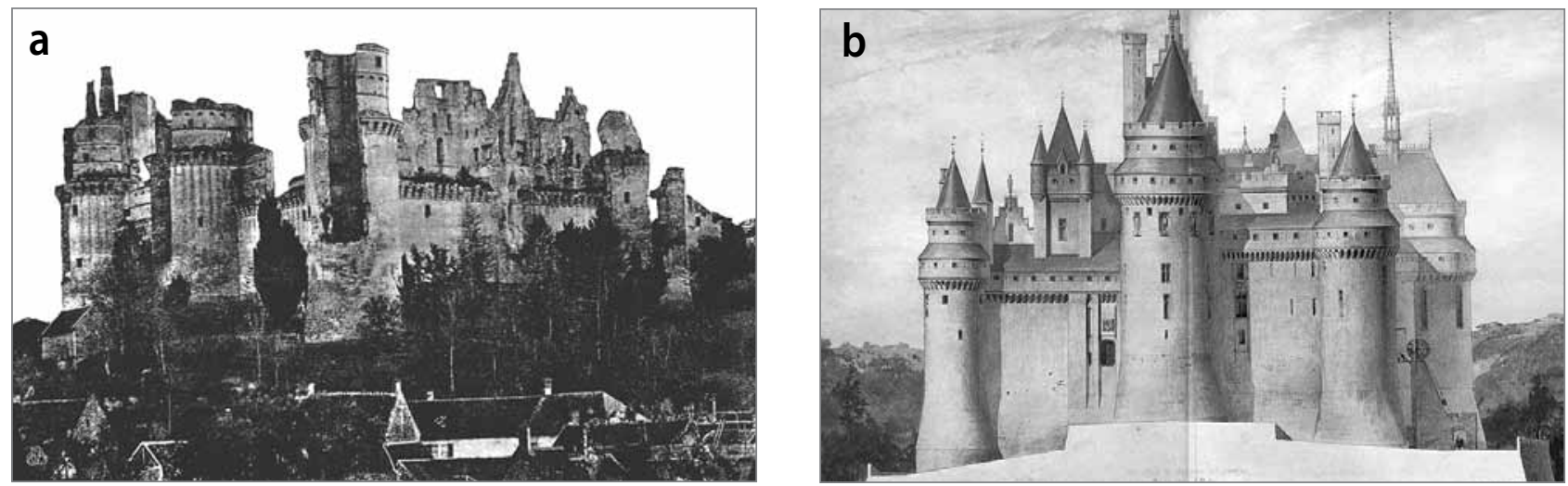

Figure 2: a) Pierrefonds Castle before restoration, Paris Photo Archives; b) Pierrefonds Castle after restoration, watercolour by Viollet-le-Duc (sources: a) Internet 3 ; b) Internet 4).

Eleventh to Sixteenth Centuries), in which he highlighted the analytical method and mentioned the concept of restoration in volume eight. He wrote the following in his dictionary: "to restore a building is not to preserve, repair, or rebuild it; it is to re-instate it in a condition of completeness that never could have existed at any given time" (Viollet-le-Duc \& Wethered, 1875: 9). Convinced that one needs to penetrate the mind of the creator of the work, he sought to answer the question of "what he [an architect] would do if he came back to the world" (Viollet-le-Duc \& Wethered, 1875: 63); he believed that only in this way can one understand the mystery of the creation, principles and origin of the architect's inspiration that supported and guided his creative work. With regard to this approach, Neil Levine (2008) highlights the issue of intentionality because these types of renovations are the result of subjective thinking regardless of the physical evidence available. The link between the idea and reality thus becomes blurred. Viollet-le-Duc focused more on the architect's thought and principles than on the building or architectural creation itself; using this philosophical approach, he ascribed himself the role of the almighty creator, believing that he could reinstate something that had not existed before and blurring his own objectivity towards what has already been created, or the original. He replaced the beauty of the individual mind with a desire to discover the impossible.

With his aggressive restoration and stylistic reconstruction, $\mathrm{Vi}$ ollet-le-Duc sought to achieve an idealist form and a generally grander architecture; he was among the first to emphasise the importance of its social and economic aspects (Choay, 2001). He wrote (1987: 87): "It is time however for our architects to think of the future; it is time we set ourselves to work to invent like our ancestors, and to regard what has been accomplished in the past ... which we should analyse in order to advance still further; it is time to think of the paramount question of economy in building". He even predicted that the economic component would take priority over other values in the future. He decisively spread the belief that architecture had to express modern thought and organically unite with existing architecture into an aesthetic whole. His main motto was: "There is no art without liberty" (1987: 475), and so he also created the most daring reconstructions of the missing parts, enjoying the full support of the political authorities of the time. Viollet-leDuc used the latest scientific and technological achievements to follow the demands of time, always taking into account the practical aspect and cost-effectiveness. In order to ensure the longest possible service life of a building, he tried to use the best and highest-quality materials in a stronger and more complete form whenever he replaced any of its parts; and he installed a new (replacement) construction element in the same place without "falsity" and "[F]ollowing this simple method of reasoning, of which any one can see the force without being versed in architectural art" (1987: 459).

In 1854 , he wrote about the importance of style and its expressiveness. His goal was to copy nature and its unmistakable principles and laws, which should be introduced sensitively into architecture, which must deliver the same perfection as only nature can (Davis, 2010). Viollet-le-Duc (1990: 233) says the following about any part of the building, its exterior and construction that needs to be restored in its own style, depending on the type and purpose of the building: "The style belongs to the narrator ... it must be style in a general sense, style that affects everyone". Because every period of art possesses a special style that creates harmony and unity in architecture, "we must adopt one of these known styles, or we must form a new one" (Viollet-le-Duc, 1987: 484).

In the nineteenth century, restoration was a synonym for rearranging and reconstructing (Orbaşli, 2008), and renovating monuments in "clean styles", or even for cleaning their surroundings; this meant it paid only little respect to the authenticity of what had been built. "I determine to be truthful", Viollet-le-Duc wrote (1987: 475). This is difficult to believe because, despite his talking about searching for the truth and avoiding falsehood in architecture, he subjected all of his crea- 

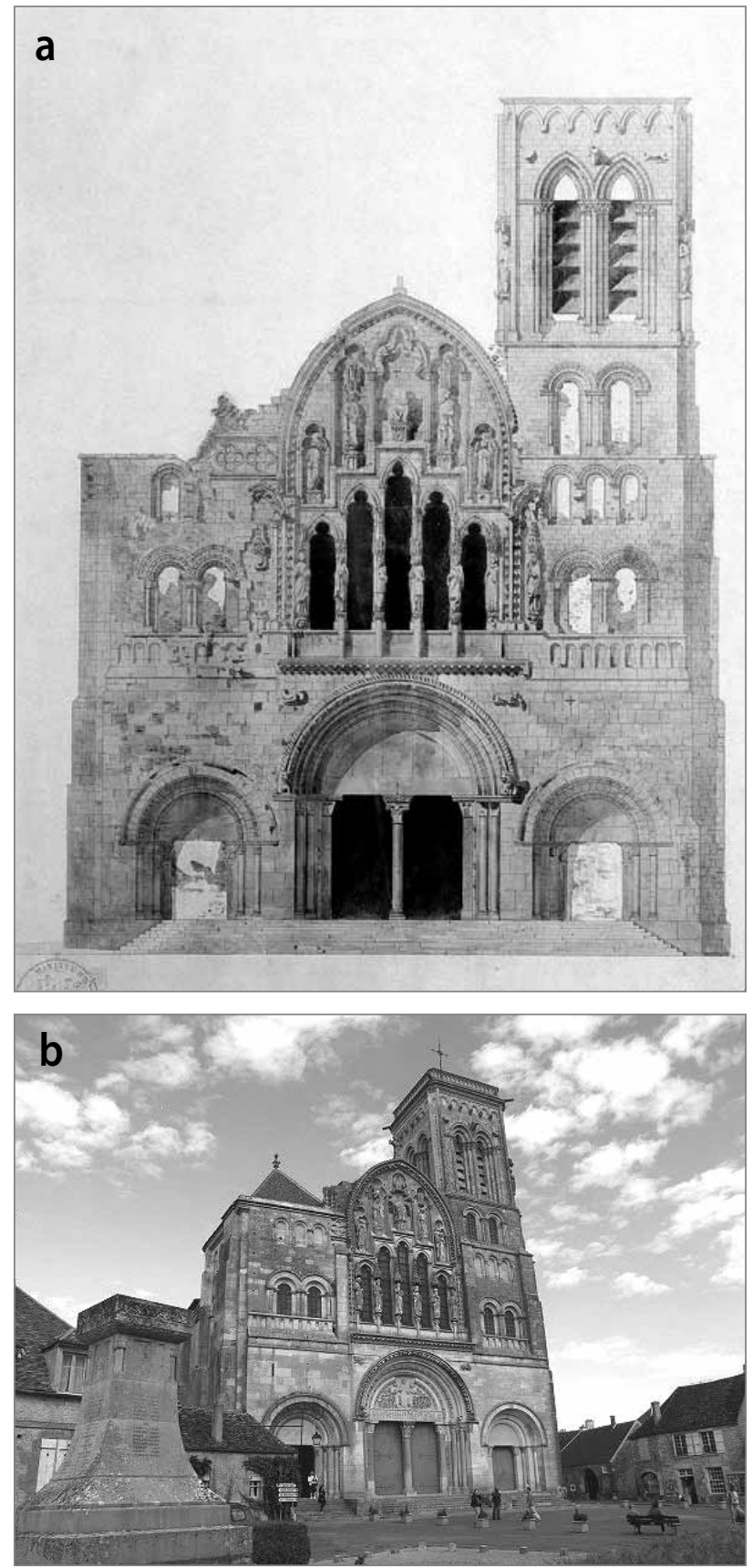

Figure 3: a) Saint Mary Magdalene Basilica in Vézelay before restoration, sketch by Viollet-le-Duc; b) Saint Mary Magdalene Basilica in Vézelay after restoration, photo by Alain Jacquot-Boileau (sources: a) Internet 5 ; b) Internet 6).

tive work to the final effect. His interventions could also be regarded as provocation, through which he challenged and recreated imaginary facts. Jorge Otero-Pailos (2005) explained historical provocation as a form of critical reflection that encourages creativity because it violates the existing rules and opens alternative paths in the interpretation of, and the interventions in, the built environment; consequently, it makes one face their responsibility of when to act. According to Otero-Pailos, provocation can only be achieved by projecting oneself into the future in order to create broader insight into the present and the past through the time perspective, and thus focus on the future anterior. He continues by listing positive examples resulting from this type of reflection. However, "future anterior" was also dealt with by Viollet-le-Duc, who used his visionary ideas to change the past because it was not grand enough. His provocations indeed pushed back the boundaries and strongly influenced the architects that came after him, but at the cost of radically altered traces of the past.

\subsection{Viollet-le-Duc's method}

In his theoretical writings, Viollet-le-Duc emphasised the importance of the principle of analogy and the method in analysis, and the principle of good judgment. The loss of originality is the consequence of a lack of thorough analysis, hence: "To arrive at synthesis we must necessarily pass through analysis" (1987: 460) because only high-quality documentation provides a sound basis for further work. "He [the restorer] should proceed like the skilful and experienced operator, who does not touch an organ until he has acquired a thorough acquaintance with its function, and provided for the immediate and remote consequences of his operation. Rather than proceed at hazard he should not undertake it. Rather let the patient die than kill him" (Viollet-le-Duc \& Wethered, 1875: 67). This is one of Viollet-le-Duc's most important observations that continues to provide the basis for relationships to architectural heritage. His greatest value before carrying out the intervention itself proceeded from his systematic study and analysis of the past. He placed comparison and the chronological ordering of events through history at the forefront, recording any changes, progress and renovations. He tried to establish the age and composition of every part before each intervention and made a report on his findings, either in writing or with a sketch, in which his skills in geometry and perspective came to the fore. Viollet-le-Duc emphasised the urgent need to familiarise oneself with the approaches of different schools because each used its own work methods, principles and styles in art. In addition to a detailed analysis of documentation, the building's anatomy, structure and character were also important. Viollet-le-Duc highlighted the use of analytical method to study and analyse details that complement one another and form a whole. He believed that every monument has its scale relative to the whole and that therefore it is key to know the original builder's scale before making any intervention, in which one must be extremely careful when adding any missing parts (Viollet-le-Duc \& Wethered, 1875). In his opinion, a restorer is only ready to work on a building correctly when he or she acquires extensive knowledge before making any interventions. "The architect should not be thoroughly satisfied, nor set his men to work until he has discovered the combination which best and most simply accords with the vestiges of ancient work: to decide on an arrangement a priori, without 
having gained all the information that should regulate it, is to fall into hypothesis; and in works of restoration nothing is so dangerous as hypothesis" (1875: 69). Based on thorough research covering the construction, materials and furnishings used, and decorations, he created an insight into the past as the basis for further interventions.

In theory, Viollet-le-Duc presented the importance of the method of analysing the building and its documentation with due precision to the benefit of the truth, but in practice he often executed interventions based on overly weak evidence in order to satisfy the "original" form or a hypothesised symmetry (Orbaşl1, 2008). As part of his restoration project at Vézelay, he made several changes by adding new construction elements in order to achieve a more perfect symmetry. He was convinced that this would give the building the originality that had not even been recorded in this form (Murphy, 2000) or, in other words: he made these changes based on a hypothesis, which he himself considered a great danger. Viollet-le-Duc explained this move as the ability to make good critical assessments on the part of the architect or restorer (Jokilehto, 1999), who is required to have a certain breadth of knowledge and skills, and who, in performing his work, is capable of deciding between restoring original and already renovated forms (Violletle-Duc \& Wethered, 1875) and adding the requisite parts in order to achieve a more perfect aesthetic form. Relying on his own intellect (i.e., that of an expert) that will give a critical assessment was of primary importance to him. He emphasised that there are no absolute principles in preservation because every monument is a unique whole and every intervention must be adapted to the monument's special features.

\section{Preserving the truth through anti- restoration}

At the other end of the extreme during the nineteenth century was the melancholic or romantic relationship to anything that was decaying. The representatives of the "conservationist" direction initiated a completely different approach to monument preservation. John Ruskin, who formed his theory in a completely different socio-political system, described Violletle-Duc's restoration as "total destruction" that is "a Lie from beginning to end"; he believed that "it is impossible ... to restore anything that has ever been great or beautiful in architecture" (1900: 184, 185). He referred to Viollet-le-Duc's quest for the "architect's truth" as an impossible, valueless approach and presented his own: "Take proper care of your monuments, and you will not need to restore them" (1900: 186). Ruskin was convinced that no one had the right to change the architect's truth out of respect for the architect and all of humankind. He also saw a connection between architecture and the human body and its soul; this soul can only be expressed through clothing or, in the case of architecture, with its most important part: the "wall veil", which he considered to be far more important than space, structure and function (Chatterjee, 2009). He was thus a fervent proponent of the untouchability of this "clothing" and wrote about the importance of proper care, supervision and maintenance, using traditional skills (Jokilehto, 1999; Kultermann, 2005) in order to preserve historical buildings as long as possible and let their decay take its natural course. Ruskin was a member of the Society for the Protection of Ancient Buildings, which was established in 1877 at William Morris' initiative as a reaction against destructive restoration. In its 1877 Manifesto, which contained guidelines for proper conservation and called against restoration and copying, which destroyed the monument's authenticity, Morris and his adherents pleaded for "protection in the place of restoration" (Pickard, 1996: 315). He described restoration as a process that caused more damage to monuments than centuries of revolution and violence, and labelled the final result of destruction and addition as a valueless forgery. Viollet-le-Duc's critics considered his approach utterly inacceptable and suggested that rather than in any way altering or repairing a building that may become inconvenient and could pose a threat to its surroundings, a new one should be built instead. They perceived monuments as examples of a "bygone art", to which modern art cannot return what time has taken away (1996).

Camillo Boito sought to find a middle way. He did not agree with the "melancholic" acceptance of the monument's natural decay, nor with the aggressive interventions that changed its image (Boito, 1893, cited in Špikić, 2006). Unlike Viollet-leDuc, who supported the idea that old structures should organically unite with new interventions, Boito says the following: "I want to make sure that everything has been documented by the original architect or was the result of his style. In every renovation it is necessary to distinguish between authentic and reconstructed parts ... There is no wisdom, no understanding in Viollet-le-Duc's theory ... only free invention, which is a lie, a falsification of the antique, a trap for posterity ... The better the restoration has been carried out, the more successfully the lie will triumph" (Boito, 1893, cited in Špikić: 317-348).

The requirement for preserving authenticity was also highlighted by others, such as Dehio, Riegl, and Dvořák; the trio advocated respect for all monument elements. Through their work, monument protection reached a level at which historical authenticity became a monument protection norm (Pirkovič, 1993). Dehio interprets his slogan, "Conserve, do not restore", as "conservation techniques are the only true cure of monument preservation" (Dehio, 1905, cited in Pirkovič, 1993: 20). Riegl's 1903 book Der moderne Denkmalkultus (The Modern Cult of Monuments) played a key role in the 
monument-protection process because it defined a system of monument-protection values that respects all elements of a monument. "He developed one of Europe's most sophisticated art-history methods", which was based on the "exact method of stylistic evaluation of works of art, ... got rid of aestheticizing norms and proclaimed the equality of styles from all periods" (Cevc, 1959: 5). Riegl divided the values into intentional and unintentional; the former already inhibit the character of a monument, whereas the latter acquire it gradually and are the main empirical subject of monument protection; as such, they exhibit greater objectivity towards the past (Pirkovič, 1993; Price et al., 1996). Riegl's theory was adopted by Dvořák, who expanded it in his manual Katechismus der Denkmalpflege (The Catechism of Monument Protection), in which he wrote about an individual's moral responsibilities. He ascribed the reasons for endangering old works of art to "negligence and ignorance, greed and fraud, misunderstood ideas of progress and the demands of the present, and inappropriate desire for beautification and renovation", and referred to the replaced architectural parts as "impersonal artistic substitutes without any artistic content" (Dvořák, 1916, cited in Mohar et al., 2011: 50).

\section{Preserving authenticity through legislation and international charters}

The first international recommendations in the form of the 1931 Athens Charter presented the general principles and guidelines for conserving and renovating historical monuments, in which the area surrounding the historical site also had to be protected. The evaluation of individual parts of a building gradually expanded to also include its surroundings (International Council on Monuments and Sites, 1931).

After the Second World War, when many monuments and even entire historical centres of towns were left in ruins, their "authenticity" was preserved through reconstruction or, in other words, reconstruction returned them to the state before the demolition or even to their allegedly authentic state (Petzet, 1994). Post-war stylistic reconstruction was harshly criticised by the 1964 Venice Charter, which called for safeguarding ancient monuments for future generations "in the full richness of their authenticity" in its preamble, but failed to clearly define this authenticity (Stovel, 1994). In addition to guidelines on monument maintenance and conservation, an entire chapter in this charter is dedicated to restoration, which should be based on respect for original material and authentic documents; restoration must stop at the point where conjecture begins. The aim of restoration is not the unity of style, but contributions of all periods must be respected; replacements of missing parts must integrate harmoniously with the existing structure, but at the same time must be distinguishable from the original (International Council on Monuments and Sites, 1964). After this fundamental work, various international documents, declarations, charters, and so on tried to define individual expressions and guidelines to ensure better heritage management. It was only in the third quarter of the twentieth century that authenticity became established as a conscious category with a significant impact on heritage protection (Gams 2010).

With the most important document in this regard, the Declaration of Amsterdam adopted in 1975, the concept of "integrated conservation" was widely established for the first time. This concept expanded the overly narrow provisions of the Venice Charter, and defined the goals and measures for heritage conservation as a non-renewable resource (Pirkovič, 2005). With later documents, the definition of this concept was expanded to include new challenges and tasks (Committee of Ministers of the Council of Europe, 1975).

The Granada Convention, adopted in 1985, elevated this concept to an international legal norm. In its preamble, the convention recognises that architectural heritage constitutes an irreplaceable expression of richness and diversity, and that it bears inestimable witness to our past that needs to be passed on to future generations. The convention treats integrated conservation somewhat more broadly, also emphasising the conservation of more modest architecture that is of interest from the point of view of its setting, and the conservation of heritage as a component part of planning and various (cultural, environmental and planning) policies. It highlights the importance of current human knowledge in the conservation of architectural heritage. In addition, the convention recognises the advantage of conserving heritage by reusing it, while preserving its architectural and historical character, and the advantage of permitting public access to protected properties, while ensuring that the consequences of permitting this access do not adversely affect the architectural and historical character of these properties (International Council on Monuments and Sites, 1985; Petrič, 2000; Pirkovič, 2005).

Many areas have been threatened, damaged and devalued by industrial development. The Washington Charter was adopted in 1987 in response to this, presenting diverse methods of planning and protecting urban and rural historical sites. Using updated guidelines, its goal was to establish the principle of the harmony of private and community life in protected areas and to encourage the preservation of material and immaterial heritage. The conservation of historic towns should be an integral part of socioeconomic development and urban and regional planning at every level (International Council on Monuments and Sites, 1987). 
The preamble to the 1999 Burra Charter advocates a cautious approach to change: "do as much as necessary to care for the place and to make it useable, but otherwise change it as little as possible so that its cultural significance is retained". The charter defines restoration as returning the monument's elements and material to a known earlier state by removing accretions or reassembling existing elements without the introduction of new material. Reconstruction is defined as returning a place to a known earlier state by adding new material or parts to the existing structure, and is appropriate only where a place is incomplete through damage or alteration. Both procedures are acceptable only if there is sufficient documentation on and evidence of an earlier state (International Council on Monuments and Sites Australia, 1999).

The Krakow Charter was published in 2000, but it was not developed by professional organisations, which is both its weakness and strength (Pirkovič 2003). The notion of modern conservation gradually includes an increasing number of tasks and approaches; hence, Article 1 of the charter stipulates that conservation can be realised by different types of interventions, including restoration and reconstruction. Both approaches are united in the same concept, and they complement rather than oppose one another. The charter advocates the fact that restoration should be carried out "appropriately", by respecting all stylistic periods and preserving the monument's authenticity and integrity. The reconstruction of entire parts "in the style of the building" should be avoided. The reconstruction of smaller parts with architectural significance is acceptable if it is based on indisputable documentation. The reconstruction of more extensive spatial parts is allowed to enable more appropriate and functional use of the building, but only as a reflection of contemporary architecture (De Naeyer, 2000; Martín-Hernández, 2007).

The Riga Charter, also published in 2000, focuses on reconstruction. In principle, it is against it, except in circumstances where reconstruction is necessary for the survival of a place that is incomplete due to damage or natural or human alteration, and where it recovers the integrity of the place under the condition that it does not compromise the existing in situ remains. It is allowed when the monument concerned has outstanding artistic, symbolic or environmental (whether urban or rural) significance for regional history and culture. Appropriate survey and historical documentation (including iconographic, archival or material evidence) must be available before any reconstruction. Authenticity is defined as a measure of the degree to which the attributes of cultural heritage (including form and design, materials and substance, use and function, traditions and techniques, location and setting, spirit and feeling, and other factors) credibly and accurately bear witness to their significance (International Centre for the Study of the Preservation and Restoration of Cultural Property, 2000).

The main document on authenticity is the Nara Document on Authenticity adopted in 1994 at the Nara Conference on Authenticity. It builds upon the Venice Charter and extends its areas of interests, emphasising cultural diversity. In the changing world of globalization, the essential contribution made by the consideration of authenticity is to clarify and illuminate the collective memory of humanity. The diversity of cultures and their heritage is an irreplaceable source of spiritual and intellectual richness for all humankind. The concept of authenticity is covered broadly in this document; it is not defined as a value and there is no single definition of what is authentic (International Council on Monuments and Sites, 1994; Višnar, 1997).

\section{A case study: monument protection in Slovenia}

The medieval historical architectural style typical of the nineteenth century had a significant influence on the design of Slovenian towns, especially churches and secular buildings. Slovenian style trends were also influenced by the activities of the Graz Society for Decorative Arts, which was established in 1864 and "advocated the principles of clean historical styles and historicizing in decorative arts, and thus also in architecture and the renovation of historical monuments" (Baš, 1955: 20). Stele (1886-1972) wrote the following about nineteenthcentury architecture: "This is how terrible monotony and coldness spread throughout the land ..., which despised artistic monuments of the past and even believed it could repair them ..." (1924: 94, 95); despite his negative opinion, Stele acknowledges a certain degree of quality of some works.

Stele was a student of Dvořák, the founder of the Slovenian monument protection theory, the only professional conservation specialist during the interwar period and the most important writer of seminal technical works (Pirkovič, 1993). $\mathrm{He}$ borrowed the key elements of the Austrian monument protection doctrine and combined them with his own beliefs and interpretation of monument protection methods. Emilijan Cevc (1920-2006) described him as a profound researcher that critically advocated what was modern while respecting what was old, thereby encompassing both (1959).

Stele provides the broadest definition of the concept of monuments, encompassing all areas of human life that have both a subjective and objective commemorative value (see Stele, 1935), and preserved the memory of the past for more than sixty years after they were created (see Stele, 1928). In contrast to Riegl and Dvořák, who primarily emphasised the theoretical aspect of conservation, Stele's first goal was to familiarise 

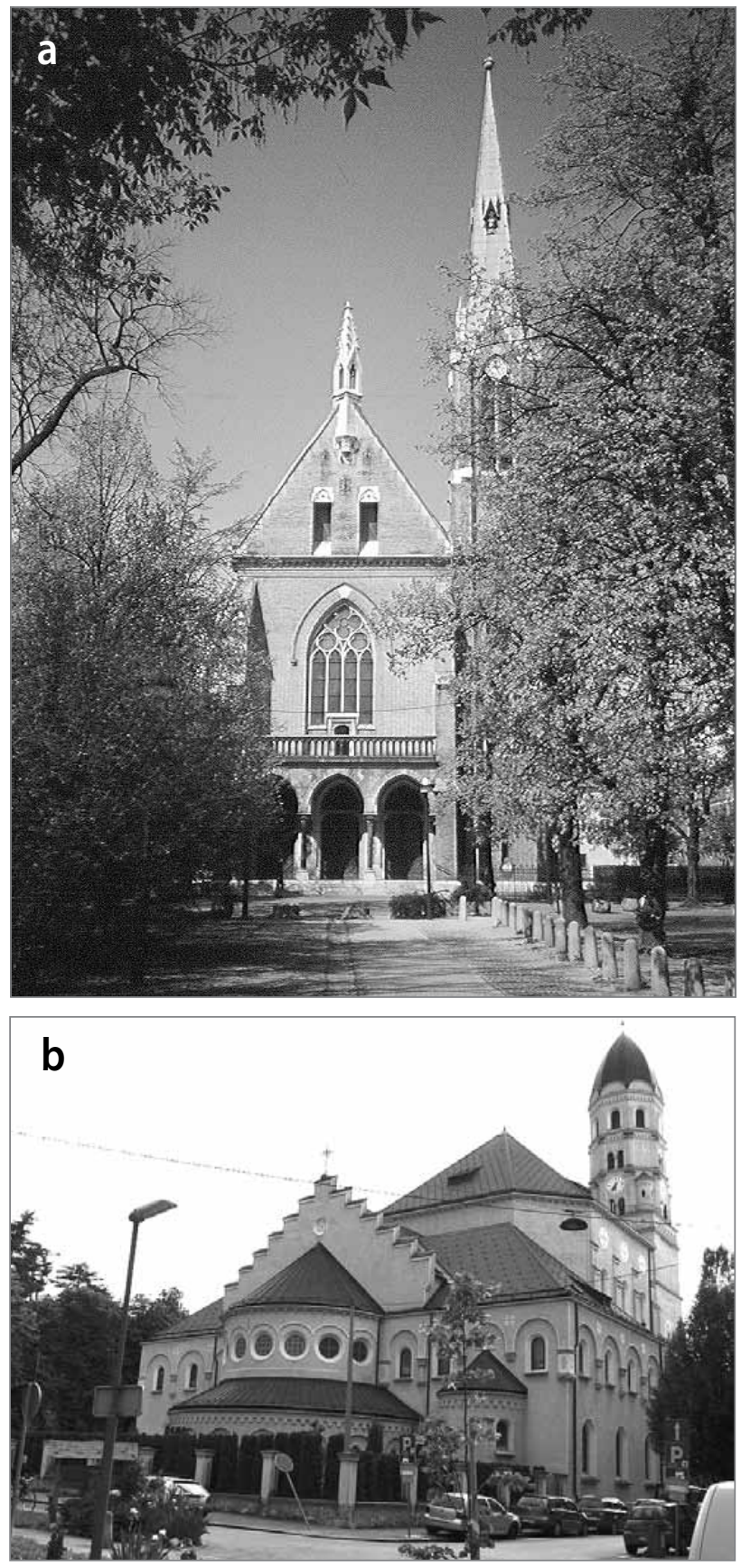

Figure 4: a) Sacred Heart Church in Ljubljana, photo by Lojze Gajšek; b) St. Joseph's Church in Ljubljana, photo by Mark Ahsmann (sources: a) Internet 7 ; b) Internet 8).

the general public with monument preservation, and arouse respect and responsibility towards the richness of the past.

He highlighted the principle of "conserve, do not restore", but he slightly modified the theory of his predecessors. In his article "Aesthetics and Documentation in Monument Restoration" (Sln. Estetika in dokumentarnost v restavriranju spomenikov), he explains the personality of a monument - with greater sensitivity to artistic values - as a series of documentary historical, emotional and "neglected" aesthetic values to which he ascribed an important role; the conservationist's role is to improve their potential. This in particular is where the greatest deviation from Riegl's and also Dvořák's thinking can be observed, in which it is clear that Stele is approaching a different line of thinking. Based on Stele's argumentation of the aesthetic value of monuments, Jelka Pirkovič (1989) concludes that monument protection is also art because nowhere in his writings does Stele talk about an opposition between monument protection and architectural design (Hoyer, 1997).

In cases where conservation is insufficient, Stele allows restoration, whose purpose is "also to give the object concerned a renovated external image in a decent form", but needs to ensure it preserves the documentary values, which he defines fairly narrowly as inscriptions (including years) and the like (1928: 180). He says the following about reconstruction and replacing missing parts with new ones: "it must firstly be a copy of what has been destroyed and secondly, it has to be added to the old structure in such a way that it does not interfere with it and unites with it into a harmonic whole" (Stele, 1965: 37, 38). This approach opposes Riegl's belief, according to which this type of interventions cause a loss of commemorative values. Riegl only allows them in exceptional cases, where the monument's applied value prevails overs its heritage values (Pirkovič, 1993).

Stele explains that the reason for updating monuments is that such "an intervention by an sensitive architect may increase the modest potential of the whole" (1953-1954: 10); he discusses the same thing in his article "The Issue of Monument Protection in Slovenian Towns" (Sln. Problem varstva spomenikov v slovenskih mestih, 1936), in which he mentions that a "sensitive architect" must introduce such a general atmosphere that brings the new creation to the fore. This idea also guided Viollet-le-Duc's creation of new architecture; both Stele and Viollet-le-Duc justified artistic creativity as something that improves the monument's presentation, but Stele nonetheless did not adhere to the same artistic creativity that was explained and carried out by Viollet-le-Duc. The manifestation or aesthetic image in Viollet-le-Duc's interventions was directly connected with purity of the style and at the same time neglected the importance of originality; in contrast, Ruskin valued the originality of the substance more than the aesthetic image of the monument (Mikuž, 1997). Stele interpreted the aesthetic potential as a mix of equal factors that interact with one another and form an entire organism and its role in relation to the setting, which is why he disagreed with the expressiveness of pure styles and advocated the importance of the harmony of all aesthetic elements of a monument regardless of the style, material and time of creation (see Stele, 1953-1954). He confirmed his dissatisfaction with certain renovations by referring to them as "unaesthetic later junk" and, according to him, an 
architect's creative spirit is only justified when he is in a subordinate position to the existing structure (Stele, 1936: 34).

A breaking point was reached during the post-war period, which due to the significant damage caused during the war is known for extensive reconstruction that exceeded professionals' expertise (Železnik, 1965) and became an "authentic" reflection of that time. Opposition to the Vienna heritage preservation doctrine can also be observed in Milan Železnik (1929-1987), who interprets the originality of the monument as a "complex of individual components, the relations between which lend the monument its essential personal image", (1960-1961: 48) and advocates the preservation of only those elements that help present the monument in its greater originality. Hence, for monuments with various styles he only allows the option of removing certain parts and adding new ones that provide a more complete aesthetic image and help increase the monument's original character. The decision on what to preserve from individual periods and what to sacrifice to the benefit of the overall image is left to the conservationist. In the 1970s, Ivan Sedej (1934-1997) drew attention to the fact that heritage protection should go beyond the mere protection of remains: "One needs to go beyond Viollet-leDuc's evaluation method, which a priori ranks higher anything that is older and sacrifices all later values, including invaluable documents, to ideal reconstruction" (1974: 17).

In his article on the authenticity of Partisan monuments, Ivan Komelj (1923-1985) claims that monument presentation often overshadows the authenticity of a historical site, but eventually this site identifies with this presentation (see Komelj, 1985). He is prepared to sacrifice authenticity for suitable presentation because, in addition to seeking the original image, he also allows the reconstruction of new parts that will re-establish a "harmonious atmosphere" (1960, cited in Pirkovič, 1993: 41).

With the introduction of the Venice Charter, a belief slowly prevailed that reconstruction can only be successful if there is sufficient documentation and evidence that leaves no doubt about the original state. In her 1993 book, in which she analysed the discipline of monument protection in Slovenia and the discrepancies between theoretical orientations and execution in practice over a thirty-year period, Maja Črepinšek confirms that reconstruction was extremely common in Slovenia even several decades after that because the goal was to enhance the aesthetic value of monuments. The resulting findings confirm the dilemma between the proper presentation of heritage and the all too frequent decisions in favour of trendy reconstruction, because heritage protection easily turned into introducing style trends favoured by the expert concerned. Trendy reconstruction was largely carried out on higher-quality buildings, in designing decorative architectural parts, all with a flair of modernity and the conservationist's personal preference, and in presenting what was mostly the oldest construction phase. According to Črepinšek, the reason for this lay in the lack of arguments supporting the decision on the manner of presentation and the desire to recreate elements in order to achieve greater appeal and expressiveness of the building, and subsequent greater economic performance. However, conservationists themselves also doubted the appropriateness of their reconstruction; this is confirmed by the fact that they also allowed later removal of added parts and repeated execution, but only if sufficient documentation was provided. Historical documentation, evidence and material about the monument generally form the fundamental theoretical basis for any intervention into heritage, and, combined with the intellect of various experts, it can lead to a wide range of results. Therefore, every expert bears the responsibility for and the burden of carrying out high-quality interventions for the benefit of future generations.

Rigid conservationist principles have gradually opened up to aesthetics and the required economy of life, but reconstruction continues to be perceived as a "falsification of the past" and too little regard is being paid to it as a form of conservation (Kavčič, 2005: 26). However, Jelka Pirkovič (2003) confirms the opposite, wondering why over the past fifty years monument protection in Slovenia has been defined more as a conservationist direction rather than restoration or reconstruction, even though a completely different picture can be observed in practice.

An overview of Slovenian legislation adopted in recent years shows deficiencies or inconsistencies in relation to heritage. The 1999 Cultural Heritage Protection Act (Sln. Zakon o varstvu kulturne dedišcine, Ur. 1. RS, no. 7/1999) does not provide a detailed definition of reconstruction; among its fundamental objectives, it only mentions maintenance and restoration of heritage and the prevention of risks and interventions that might alter its characteristics, content, form and hence its value. Safeguarding authenticity is defined in somewhat greater detail in Resolution no. 1 (Sln. Resolucija št. 1), which deals with the role of cultural heritage and the challenges of globalization, calling for the improvement and protection of the authenticity and pristine nature of cultural heritage, and advising against reproduction of structures, except in rare cases where its integrity is to be safeguarded (Pirkovič, 2003).

A detailed definition of reconstruction is provided only in construction legislation, specifically in the Construction Act (Sln. Zakon ograditvi objektov, Ur.1 RS, no. 110/2002: 13086), which defines it as "changing the technical characteristics of an existing building and adapting this building to altered use 
or needs, or executing works that do not significantly alter the size, exterior and intended use of the building, but change the construction elements and capacity and introduce other improvements". "Significant changes" are specified ambiguously as are "other improvements", which are not clearly defined and allow changes provided that the external form is retained fairly intact.

The Cultural Heritage Protection Act (Sln. Zakon o varstun kulturne dedišine, Ur. l. RS, no. 16/2008: 1122) finally provided a definition of "integrated conservation": "a series of measures to ensure the further existence and enrichment of heritage, its maintenance, renovation, renewal, use and revival". Reconstruction is not mentioned and may perhaps only be equated with a "compensatory measure, which is an activity, intervention or act that replaces or mitigates the loss or damage of heritage".

\section{Conclusion}

In the past, various approaches to heritage preservation were developed with their own unique guidelines and views that have gradually been updated and ultimately presented the key steps in the development of modern monument protection doctrine; they ranged from narrow, specialised views to more generally conceived principles of sustainable development. These principles are to preserve cultural heritage by respecting regional, local and individual special features and natural elements, fulfilling the needs of modern society without threatening heritage for future generations, and using heritage special features to the benefit of balanced spatial development (Petrič, 2000; Jogan, 2008; Fister, 2009).

Cultural heritage is an asset that presents a nation's identity, and as such is an irreplaceable value and a proof on the history of the humankind. Therefore, we should strive as much as possible to preserve it in its original and intact state, which is a goal that is both extremely demanding and difficult to achieve. "The fate of monuments lies in three options: destruction, decay or alteration. Protective measures may temporarily delay this fate, but only at the cost of increasing alteration each time" (Pirkovič, 1993: 69).

By changing the monument, Viollet-le-Duc sought to fulfil his demand for seeking the truth, whereby he ascribed himself the role of the almighty creator that has the ability to understand and replace the original builder. He even went a step further in seeking "what is real", developing an approach that left behind significantly changed monuments. As early as the nineteenth century, the opponents of these principles strictly rejected this approach and believed in maintaining, taking care of and supervising the monument and facing its natural decay. Even though Viollet-le-Duc's approach involved a fairly distorted search for authenticity, one can sense an awareness and a need to return integrity to the monument. This need can be still observed today, although through a different mind-set, by taking into account and learning from the mistakes and extremes of the nineteenth century. Monument protection in Slovenia emphasises a commitment to the strict conservationist principles of the Vienna school, which were adopted and advocated by Stele, the most important Slovenian writer of technical works. However, he interpreted some parts differently and even allowed interventions that were opposed by the Austrian heritage protection doctrine. Deviations can also be found in technical texts by other conservationists and especially in practice, which testifies to a multitude of reconstructions and restorations carried out not only after the war, when such interventions became common due to extensive wartime damage, but also several decades after that.

The French architect and theoretician's greatest contribution to future generations was his emphasis on the importance of systematic study and analysis of both the past and the monument in question. Collecting and studying historical sources and documents, and conducting thorough research on the monument, its construction, scale, furnishings, decorations, changes and even the tiniest bits of information that makes up the complex whole form the basis for making further decisions on interfering with this sensitive structure. However, the retrospective view and research on the monument make up only part of the reflection in this complex task because there has always been and always will be the question of whether to "conserve or restore", which continues to cause disagreement in relation to heritage.

People have always wondered how they can best care for heritage that has been given to them for safekeeping, so that future generations will also be able to admire its grandeur and assume the same task. The historical extremes presented in this article demonstrate that various approaches to monuments have been sought and a wide range of results have been achieved. Only time will tell how successfully these interventions have been executed. Even today, when one seeks to do a good job, just as people have done in the preceding decades and centuries, the question remains whether the job is being performed well. I agree with Viollet-le-Duc's view that every monument is an individual structure that requires individual care. It is most likely due to these heritage special features that there is so much disagreement with regard to conservation and this is how it will probably continue to be in the future. I would like to conclude this article with Edvard Ravnikar's (1956: 150) thought on architecture: "it copies nothing, but only weaves the shell of space from the rough material... How to make this shell 
well" and preserve and protect it "will always remain one of the main areas of thinking about life and architecture as well".

\section{Helena Kalčić}

University of Ljubljana, Faculty of Architecture, Slovenia

E-mail: helena.kalcic@gmail.com

\section{References}

Baš, F. (1955) Organizacija spomeniškega varstva v slovenski preteklosti. Varstvo spomenikov, 5, pp. 13-37.

Campa, M. (2009) E. E. Viollet-le-Duc: Innovation and tradition in architecture. Language of form and structure in the conception of polyhedral vaults. In: Kurrer, K., Lorenz, W. \& Wetzk, V. (eds.) Proceedings of the third international congress on construction history. Cottbus, Chair of Construction History and Structural Preservation of the Brandenburg University of Technology.

Čepaityte Gams, O. A. (2010) Dediščina in vprašanje avtentičnosti: kaj (rekonstruiramo). In: Jezernik, B. (ed.) Kulturna dediščina in identiteta, pp. 109-136. Ljubljana, Znanstvena založba Filozofske fakultete.

Cevc, E. (1959) France Stele - umetnostni zgodovinar. Zbornik za umetnostno zgodovino, 5(6), pp. 5-19.

Chatterjee, A. (2009) Tectonic into textile: John Ruskin and his obsession with the architectural surface. Textile: The Journal of Cloth \& Culture, 7(1), pp. 68-97. DOI: 10.2752/175183509X411771

Choay, F. (2001) The invention of the historic monument. Cambridge, Cambridge University Press.

Committee of Ministers of the Council of Europe (1975) The Declaration of Amsterdam. Available at: http://www.icomos.org (accessed 12 Mar. 2014).

Črepinšek, M. (1993) Prenova stavbne dediščine v Sloveniji. Ljubljana, Restavratorski center Republike Slovenije.

Davis, C. L. (2010) Viollet-le-duc and the body: The metaphorical integrations of race and style in structural rationalism. Arq: Architectural Research Quarterly, 14(4), pp. 341-348. DOI: 10.1017/S1359135511000133

De Naeyer, A., Arroyo, S. P. \& Blaco, J. R. (2000) Krakow charter 2000: Principles for conservation and restoration of built heritage. Krakow, Bureau Krakow 2000.

Dvořák, M. (2011) Katekisem spomeniškega varstva (Dunaj 1916). Umetnostna kronika, 32, pp. 44-50.

Fister, P. (2009) Identiteta kot vrednota arhitekturne dediščine. Koroški vestnik, 43(1-3), pp. 153-160.

Frampton, K. (1992) Moderna arhitektura: kritička povijest. Zagreb, Globus.

Giliberti, M. (2013) Rethinking the memorial in a Black Belt landscape: Planning, memory and identity of African Americans in Alabama. Urbani izziv, 24(1), pp. 144-159. DOI: 10.5379/urbani-izziv-en-2013-24-01-004

Hoyer, S. A. (1997) Konservatorska doktrina na Slovenskem. In: Hoyer, S. A. (ed.) Umetnostna zgodovina in spomeniško varstvo, pp. 33-42. Ljubljana, Slovensko umetnostnozgodovinsko društvo.

International Centre for the Study of the Preservation and Restoration of Cultural Property (2000) The Riga Charter. Available at: www. helm.org.uk/guidance-library/re-arch/re-arch2001.pdf (accessed 12 Mar. 2014).

International Council on Monuments and Sites (1931) The Athens Charter. Available at: http://www.icomos.org (accessed 12 Mar. 2014).
International Council on Monuments and Sites (1964) The Venice Charter. Available at: http://www.icomos.org (accessed 12 Mar. 2014).

International Council on Monuments and Sites (1985) The Granada Convention. Available at: http://www.icomos.org (accessed 12 Mar. 2014).

International Council on Monuments and Sites (1987) The Washington Charter. Available at: http://www.icomos.org (accessed 12 Mar. 2014).

International Council on Monuments and Sites (1994) Nara Conference on Authenticity. Available at: www.helm.org.uk (accessed 5 Apr. 2014).

International Council on Monuments and Sites Australia (1999) The Burra Charter. Available at: www.icomos.org/australia (accessed 12 Mar. 2014).

Internet 1: http://ap1y2.blogspot.com/2012_01_01_archive.html (accessed 15 Sept. 2014).

Internet 2: http://www.studyblue.com/notes/note/n/monumentsexam-1/deck/7776055 (accessed 15 Sept. 2014).

Internet 3: http://www.raybishophistory.co.uk/lawrence-rides-southand-into-the-middles-ages/a-selection-of-castles-visited-by-lawrence/ pierrefonds/ (accessed 15 Sept. 2014).

Internet 4: http://corbuscave.blogspot.com/2011_04_01_archive.html (accessed 15 Sept. 2014).

Internet 5: http://www.histoire-image.org/site/zoom/zoom. php?i=856\&oe_zoom=1553 (accessed 15 Sept. 2014).

Internet 6: http://jacquotboileaualain.over-blog.com/article-vezelayyonne-109207365.html (accessed 15 Sept. 2014).

Internet 7: http://www.brezmadezna.com/md/lj/ljubljana.htm (accessed 15 Sept. 2014).

Internet 8: http://commons.wikimedia.org (accessed 15 Sept. 2014).

Jogan, S. (2008) Pravno varstvo dediščine: ogrožanje in uničevnje kulturne in naravne dediščine ter pravni vidiki njunega varstva. Koper, Založba Annales.

Jokilehto, J. (1999) A history of architectural conservation. Oxford, Butterworth-Heinemann.

Kavčič, M. (2005) Problematika rekonstrukcije pri ohranjanju spomenikov. AR: arhitektura, raziskave, 6(1), pp. 26-31.

Komelj, I. (1985) Avtentičnost "avtentičnih" spomenikov NOB. Varstvo spomenikov, 27, pp. 49-52.

Kultermann, U. (2005) John Ruskin - art and the passion for nature (steps towards a re-evaluation). Zbornik za umetnostno zgodovino, 41(1), pp. 236-245.

Lah, L. (2001) From architectural conservation, renewal and rehabilitation to integral heritage protection (theoretical and conceptual starting points). Urbani izziv, 12(1), pp. 129-137.

DOI: 10.5379/urbani-izziv-en-2001-12-01-004

Lazarini, F. (2012) Cerkvena arhitektura Lavantinske škofije v času knezoškofa dr. Mihaela Napotnika (1889-1922). Doctoral thesis. Maribor, University of Maribor, Faculty of Arts.

Levine, N. (2008) Building the unbuilt: authenticity and the archive. Journal of the Society of architectural historians, 67(1), pp. 14-17.

Martín-Hernández, M. J. (2007) Architecture from architecture: Encounters between conservation and restoration. Future Anterior, 4(2), pp. 62-69.

Mikuž, J. (1997) Spomenik: konservator: restavrator. In: Hoyer, S. A. (ed.) Umetnostna zgodovina in spomeniško varstvo, pp. 51-58. Ljubljana, Slovensko umetnostnozgodovinsko društvo.

Murphy, K. (2000) Memory and modernity, Viollet-le-Duc at Vézelay. 
University Park, Pennsylvania State University Press.

Mušič, M. (1963) Arhitektura in čas: eseji in razprave. Maribor, Obzorja.

Orbaşli, A. (2008) Architectural conservation: Principles and practice. Oxford, Blackwell.

Otero-Pailos, J. (2005) Historic provocation: Thinking past architecture and preservation. Future Anterior, 2(2), pp. 2-6.

Petrič, M. (2000) Mednarodno pravno varstvo kulturne dediščine. Vest$n i k, 17$, pp. 69-74.

Petzet, M. (1994) In the full richness of their authenticity - The test of authenticity and the new cult of monuments. In: Larsen, K. E. (ed.) Nara conference on authenticity, pp. 294-309. Paris, UNESCO World Heritage Centre.

Pickard, R. D. (1996) Conservation in the built environment. Harlow, Longman.

Pirkovič, J. (1989) Vpliv avstrijske teorije na Steletov spomeniškovarstveni nazor. Varstvo spomenikov, 31, pp. 113-124.

Pirkovič, J. (1993) Osnovni pojmi in zasnova spomeniškega varstva $v$ Sloveniji. Ljubljana, Zavod RS za varstvo naravne in kulturne dediščine.

Pirkovič, J. (2003) Reproduciranje izginulih spomenikov in vprašanje pristnosti. Varstvo Spomenikov, 40, pp. 209-221.

Pirkovič, J. (2005) Celostno ohranjanje naselbinske dediščine. Ljubljana, Zavod za varstvo kulturne dediščine Slovenije.

Price, N. S., Talley, M. K. \& Melucco Vaccaro, A. (eds.) (1996) Historical and philosophical issues in the conservation of cultural heritage. Los Angeles, The Getty Conservation Institute.

Ravnikar, E. (1956) Arhitektura - Tri knjige o arhitekturi. Naša sodobnost, 4(2), pp. 142-152.

Ruskin, J. (1900): The seven lamps of architecture. Boston, Boston Dana Estes \& Company Publishers.

Sedej, I. (1974) Prispevek $h$ konservatorski metodologiji in teoriji. Ljubljana, no publisher.

Špikić, M. (2006) Anatomija povijesnoga spomenika. Zagreb, Institut za povijest umjetnosti.

Stele, F. (1924) Oris zgodovine umetnosti pri Slovencih. Ljubljana, Nova založba.

Stele, F. (1928) Osnovna načela varstva spomenikov. Časopis za zgodovino in narodopisje, 23, pp. 179-185.

Stele, F. (1935) Problem spomeniškega varstva v Jugoslaviji. Jugoslovenski istorijski časopis, pp. 425-454.

Stele, F. (1936) Problem varstva spomenikov v slovenskih mestih. Kronika slovenskih mest, 3(1-4), pp. 31-37.

Stele, F. (1953-1954) Estetika in dokumentarnost v restavriranju spomenikov. Varstvo spomenikov, 5, pp. 5-13.

Stele, F. (1965) Iz konservatorskih spominov. Varstvo spomenikov, 20, pp. 13-38.

Stovel, H. (1994) Note on aspects of authenticity. In: Larsen, K. E. \& Larstein, N. (eds.) Conference on authenticity in relation to the world heritage convention, pp. 101-116. Oslo, Riksantikvaren, Directorate for Cultural Heritage.

Viollet-le-Duc, E. E. (1987) Lectures on architecture: in two volumes. New York, Dover publications.

Viollet-le-Duc, E .E. (1990) The foundations of architecture: selections from the Dictionnaire raisonné. New York, G. Braziller.
Viollet-le-Duc, E. E. \& Wethered, C. (1875) On restoration and a notice of his works in connection with the historical monuments of France. London, Sampson Low, Marston Low and Searle.

Višnar, K. (1997) Pojem avtentičnega v konservatorstvu. Varstvo spomenikov, 37, pp. 24-31.

Zakon o varstvu kulturne dediščine. Uradni list Republike Slovenije, no. 7/1999. Ljubljana.

Zakon o graditvi objektov. Uradni list Republike Slovenije, no. 110/2002. Ljubljana.

Zakon o varstvu kulturne dediščine. Uradni list Republike Slovenije, no. 16/2008. Ljubljana.

Železnik, M. (1960-1961) O prvobitni podobi likovnih spomenikov. Varstvo spomenikov, 8, pp. 48-55.

Železnik, M. (1965) Stara mestna jedra in nekatere nujne naloge spomeniške službe. Varstvo spomenikov, 10, pp. 85-94.

Železnik, M. (1981) Varstvo integritete kulturnih spomenikov. Sinteza, 53-54, pp. 65-66. 